\title{
研究薄板の横衝撃変形運動に対する板厚 $\delta_{0}$ の意味 ${ }^{*}$
}

\author{
泉四郎** 坂田正登** 满田博宣***
}

The Meaning of the Plate Thickness $\delta_{0}$ in the Deformation of

Thin Plate under Lateral Impact

Shirō Izumi, Masato Sakata, Hironobu Mitsuda

The two theories gave a nearly satisfactory solution for a problem about the mysterious flexibility shown in high-energy-rate-forming of a hard metal. The one is the deformation theory of zero-thickness-plate under lateral impact, and the other that of strain-wave-stracture which states about the thickness-criterion indicating the limit of application of the zero-thickness-theory, using the strain-wave which is deduced from the same theory. But it was found afterwards that the theoretical wave form differed a little from the observed one. And to clean up discrepancy and related conflicts, New Deformation Theory has been developed, under the consideration of the plate thickness $\boldsymbol{\delta}_{0}$. The main results are summarized as follows:

1. If we consider merely the changing profile of a thin plate, its deformation is well explained by the theory of zero-thickness-plate.

2. If the strain of plate comes into question, there must be considered the longitudinal elongation infront of the material point where the maximum curvature $\kappa_{0}$ occurs. The strain $\varepsilon$ is given by: $\varepsilon=\frac{1}{2} \kappa_{0} \delta_{0}\left(\frac{\delta_{c}}{\gamma_{c}-\gamma}\right)^{2}\left(\frac{\gamma_{t}^{t}}{\xi}-\frac{\gamma}{\gamma_{c}}\right)^{2}$, where $\gamma$ : the velocity of propagation of the maximum curvature $\kappa_{0}$ along the plate, $\gamma_{c}$ : that of sound, $\xi$ : the original coordinate of the specific particle-point on the material-plate, and $t$ : the time measured from the instant when the impact begins.

3. In the portion by where the maximum curvature has past, the strain $\varepsilon$ increases from $\frac{1}{2} \kappa_{0} \partial_{0}$ to $\frac{1}{2}(U / c)^{2}$, where $c$ : the horizontal velocity of propagation of the maximum curvature $\kappa_{0}$ relative to the space-fixed-coordinate-system, and there the deforming motion occurs almost entirely in accordance with the theory of zero-thickness-plate.

\section{1. 緒言}

第 2 報1 2 は 0 板厚の横衝撃変形理論および厚さ $\delta_{0}$ の板 が衝撃変形において示す柔軟性の説明とその柔軟性をう みだす条件を求めるための塑性波構造論を述べた．前者 は曲率変化に無抵抗な理想上の板の変形運動論である が，第 3 報2) $0.6 \mathrm{~mm}$ の鉛板によりその験証を行なっ ている.しかしそれは曲率に関する験証にとどまり, 塑 性波構造論もある意味では 0 板厚理論波形の一部改造を 要求している. その波形についてのストレンダージを用

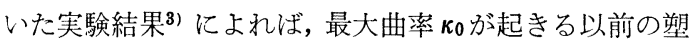
性波の時間波長がおよそ固定端からの標点距離に比例し て延びるので，それを一定長さとした塑性波構造論1)の 根本饭定とは異なる.かかる実験と理論および理論相互 閒の不一致は調整されね校らないが，これはそのため

*原稿受付 昭和46年 3 月15日. 精機学会北九州地区講演会 （昭和45年11月 5 日）にて発表.

**正 会 員 熊本大学工学部 (熊本市黑髮町)

***学生会員 熊本大学工学部
の理論である.

\section{2. 塑性波構造論および実験結果に適する波形}

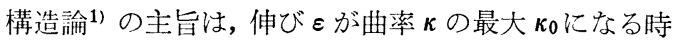
点に 0 から成長し始めるとする 0 板厚理論に対し， $\kappa_{0}$ の 出現する時点にはすでに,

$$
\varepsilon_{1}=\frac{1}{2} \kappa_{0} \delta_{0}
$$

にまで成䏍することで曲げ抵抗の台頭を押える，という 点にある. その際用いられた波形は, 0 板厚理論の $\varepsilon$ 波 そのままの形をちょうど $\varepsilon=\varepsilon_{1}$ が実現する間だけ時間軸 上を前方にずらせるのであって, そのときの時間波形 は，成長開始を $t=0$ とす机次式であった。

$$
\varepsilon=\frac{1}{2}\left(\kappa_{0} c t\right)^{2}
$$

ここに $c$ 注 $\kappa_{0}$ 位相点の $x$ (水平) 方向の速度とする.た だしこの場合 $x$ (空閒座標 $)=\xi$ (標点座標) であったか ら $c$ 涳閒速度とも対標点の速度とも考えられたが, 実 は後者の意味に解したほうが今後好都合となるので両者 
军区別するために $c$ 学対究間, $\gamma$ 学対標点の速度とし, 今後は次式起用いることにする。

$$
\varepsilon=\frac{1}{2}\left(\kappa_{0} \gamma t\right)^{2}
$$

なおっとこに衝撃条件その他一切法 0 板厚理諭の場合之 同じ条件（ただし板厚 $\delta_{0}$ 赵除いて）によるものとする

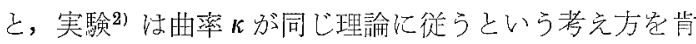
定字当.

そこで，い票標点 とし，(3)式でその成長過程学表わ告ものとし，時点 $t_{1}$ 亿

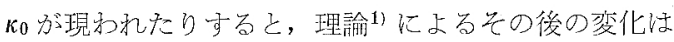

$$
\kappa=\kappa_{0}\left\{1-\frac{3}{2}\left(\kappa_{0} \gamma\right)^{2}\left(t-t_{1}\right)^{2}\right\}
$$

となるので，これに(3)式の関係等用いて：

$$
\kappa=\kappa_{0}\left\{1-3\left(\sqrt{\varepsilon}-\sqrt{\varepsilon_{1}}\right)^{2}\right\}
$$

こえ

$$
\varepsilon_{1}=\frac{1}{2}\left(\kappa_{0} \gamma t_{1}\right)^{2}
$$

となるが，構造論1で曲げ仕事と㜀び仕事との関係発計

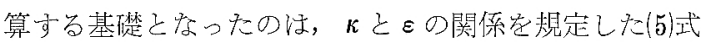
であった。皇こでこの関係の代りに，

$$
\kappa=\kappa_{0}\left\{1-3 k^{2}\left(\sqrt{\varepsilon}-\sqrt{\varepsilon_{1}}\right)^{2}\right\} \quad(k \text { : 任意定数 })
$$

安用いて，前 ${ }^{1)}$ と同じ計算它やり直してもをの絬諭话少 しも影響されないことは，その計算の跡をたどればよく わわる゙。 $k$ 加任意定数という意味は一個の標点に効し て時間的に不变であることだから，標点莡異耴すればそ の定数值は異なったとしてる推諭の頲びに变化が起きな いことに注意すると，k冠つぎのよらに選ぶことが許さ れ。.

$$
k=\frac{1}{\sqrt{2 \varepsilon_{1}}} \cdot \frac{n-1}{n} \cdot \kappa_{0} \xi
$$

ここに $\varepsilon_{1}$ と $\kappa_{0}$ は(4)，(5)式に現わ秃たのと同じもので， $n$ は弾性縱波速度の $\gamma$ に刘する比（倍率）とする．この

*塑性波構造論1 岂要約すれば，まず $\kappa_{0}$ の起きる点のひずみ 加 $\varepsilon_{1}=\frac{1}{2} \kappa_{0} \delta_{0}$ になるるうな基集波形家仮定し，乙れに対し 伸波が曲率波に対し遲机る場合，その基售からのずれ定 $\lambda=$

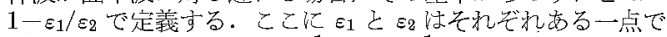
$\kappa_{0}$ の起きる時点および $\varepsilon=\frac{1}{2} \kappa \delta\left(\varepsilon_{2}=\frac{1}{2} \kappa_{2} \delta_{2}\right)$ の起きる時点

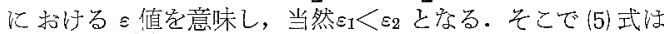
$\kappa_{2}=\kappa_{0}\left(1-\frac{3}{4} \varepsilon_{2} \lambda^{2}\right)$ になるので, ずれ $\lambda$ 小さい場合 $\varepsilon_{2} \lambda^{2} \ll$ 1 とすると $\kappa_{2} \simeq_{\kappa_{0}}$ とされる.乙の苇笑に基づいた推論の結果

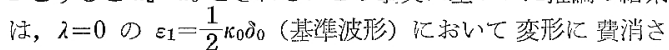
机る全仕事量流最小になると定証明している。そこでい宋 (5)の代りに(7)式の $\kappa$ 定用いると $\kappa_{2}=\left(1-\frac{3}{4} k^{2} \varepsilon_{2} \lambda^{2}\right)$ となる

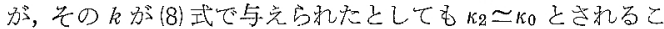
とに変わりはない。をたその优の推論证前とまったく同じ道 をたどるので結局 $\varepsilon_{1}=-\frac{1}{2} \kappa_{0} \delta_{0}$ (基準波形) で消貿仕事量最小 という同じ結諭に達する.
ような $k$ の值に対し(4)，(7)の両式が同時に成立するため の必要十分条件としてつぎの関係枵得られる。

$$
\left.\begin{array}{rl}
\varepsilon & =\varepsilon_{1}\left(\frac{n}{n-1}\right)^{2}\left(\tau-\frac{1}{n}\right)^{2 * *} \\
こ こ に \quad \tau & =\gamma t / \xi
\end{array}\right\}
$$

これは伸び

$$
\begin{aligned}
& (1 / n \leqq \tau \leqq 1) \text { また沙 }(\xi / n \gamma \leqq t \leqq \xi / \gamma) \quad(10) \\
& \text { そして： } \varepsilon=0 \quad(0 \leqq t \leqq \xi / n \gamma)
\end{aligned}
$$

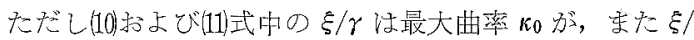

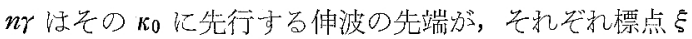
に到達するに要する時間である。そこでその差 $\xi(1-1$

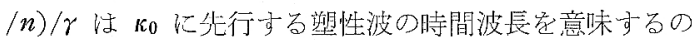

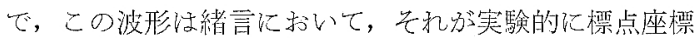

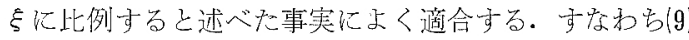

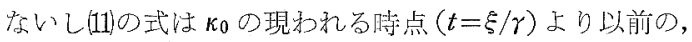
板がをだ我平店姿勢起保つと（実験的に）考光られてい る期間の波形として，構造論の立場から，もっとも一般

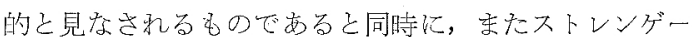
ジによる測定の波形とも和よそ一致する。上式による

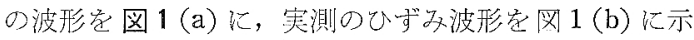
के.

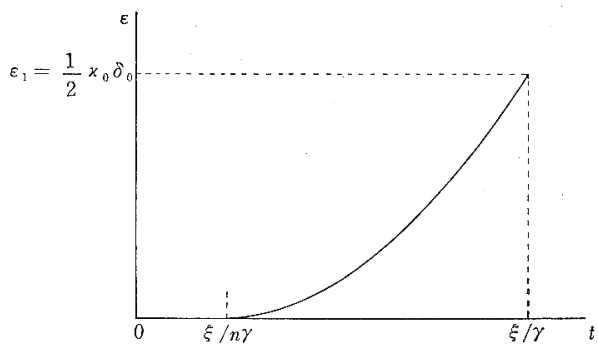

图 1 (a) $\kappa_{0}$ 以前のひず努波形

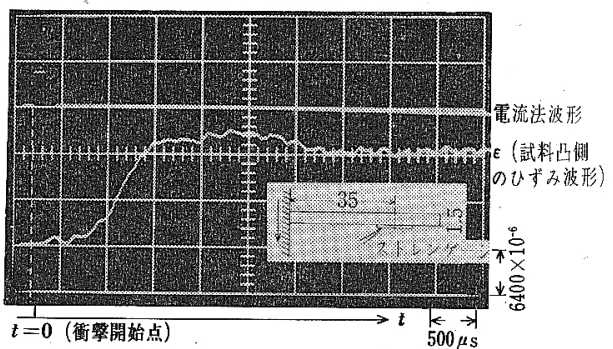

ダージ：Shinkoh F 102，試料：鉛 $(120 \times 19 \times 1.5)$ ゲージ位置： $\xi=35 \mathrm{~mm}$, 落下高さ: $1.0 \mathrm{~m}$ 増幅器： Hulett-Packard 8875 A シンクロスニープ：岩崎 DS-5302 B

図 1 (b) 実測のひずタ波形 (43.12.4 笑験)（ひずみ波形 中の小さ振動烙下体の弾性振動による)

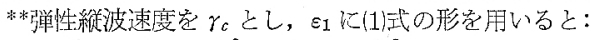
$\varepsilon=\frac{1}{2} \kappa_{\Delta} \partial_{0}\left(\frac{\gamma_{c}}{\gamma_{c}-\gamma}\right)^{2}\left(\frac{\gamma t}{\xi}-\frac{\gamma}{\gamma_{c}}\right)^{2}$ 


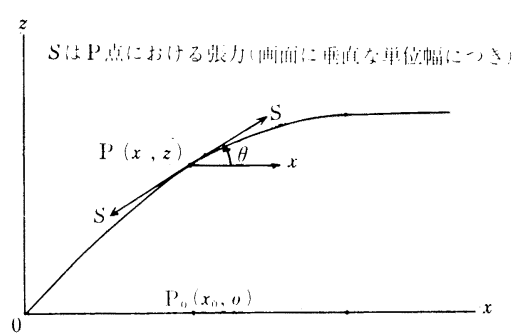

図 2 変形運動中時点 $t$ そおける板のプロフィル

\section{3. 推論の方針}

連動力程式は最初の一般型に立台帰ら衫ばならない。

$$
\begin{aligned}
& m_{0} \frac{\partial^{2} x}{\partial t^{2}}=-\frac{\partial}{\partial \xi}(S \cos \theta) \\
& m_{0} \frac{\partial^{2} z}{\partial t^{2}}=\frac{\partial}{\partial \xi}(S \sin \theta)+m_{0} \rho(t)
\end{aligned}
$$

ここに質点 $P$ の標点座槽 $\xi$, 同じく空間座標 $(x, z)$ 揬 線の傾角 $\theta$ ，抢よびその响の張力を $S$ とした（図 2). $\kappa_{0}$ 以前に試料がほとえど水平 $(\theta=0)$ の姿勢を保つとい

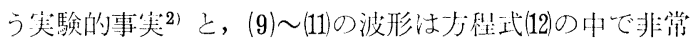
によく調和与ることは中もなく判明一るが，これと $\kappa_{0}$ 以

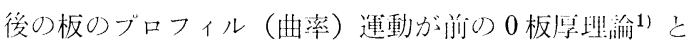

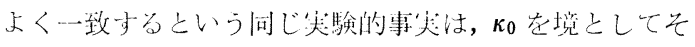
れ以葥と以後とで，現象を二分して考えたほうが問题在 手ぎわよく（止確にではないが）解決できること老睛小

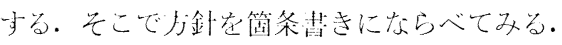

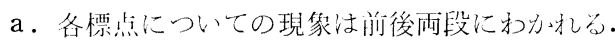

b. 㓩段では $\theta$ 老 0 とおいて, 方程式(12)が(9)〜(11)を解

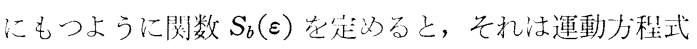
の物理的意味にしたがって前段を支配する张力阙数とな る*.

$c$. 時点 $t$ において $\xi \geqq n \gamma t$ は無ひずみ, $\gamma t \leqq \xi \leqq n \gamma t$ では(9)式のひずみが㧍きている。また板は水平であるか らその部分の標点

$$
u=-\int_{\xi}^{n \gamma t} \varepsilon \mathrm{d} \xi=\gamma t \cdot \varepsilon_{1} \frac{n}{(n-1)^{2}}\left\{\frac{n \gamma t}{\xi}-\frac{\xi}{n \gamma t}-2 l_{n} \frac{n \gamma t}{\xi}\right\}
$$

(13)

そして左端 $(\xi=\gamma t)$ には:

$$
u_{1}=-\lambda_{1} \gamma t, \quad \lambda_{1}=\varepsilon_{1} n \cdot(n-1)^{-2}\left(n-n^{-1}-2 l_{n} n\right) \text { (14) }
$$

*当面する問題での張力関数 $S_{b}(\varepsilon)$ は未知であるが, ひずみ波 形 $\varepsilon(\xi, t)$ は $(9) \sim 11)$ の形にわかっている. この $S_{b}(\varepsilon)$ 之 $\varepsilon$ $(\xi, t)$ と注運動方程式12から演えきされた(19)式の中で両立し なければならない。ここで $S_{b}(\varepsilon)$ はその式の成立時点におけ る張力としての物理的意味をもつので, むし $S_{b}(\varepsilon)$ を みの関数とすると, 当然それはこの運動に従う板（柔軟な） の張力とひずみの関係を与える（もちろんそれは真の意味で はなく近似的意味にお沙るものであるが)。なお46頁の脚注 *を参照されたい.
のずれが起こる。これを $\kappa_{0}$ 位相点について観祭㑊ると：

$$
x_{1}=\xi_{1}+u_{1}=c t, \quad c=\gamma\left(1-\lambda_{1}\right)
$$

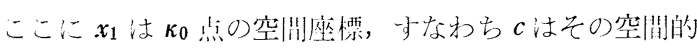

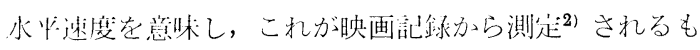
つである。

d. 後段が 0 板厚理諭に徉うというときの意味它数学 的に表現すると, 運動方程式(12)が双曲線型方程式:

$$
x=\xi\left(1-\lambda_{1}\right), \quad \frac{\partial^{2} z}{\partial t^{2}}-c^{2} \frac{\partial^{2} z}{\partial x^{2}}=\varphi(t)
$$

に苦き直されるということに他ならないこの書き換え が可能であるための必要十分条件として, 後段では運動 方程式(12)のおのがつぎの形をもつことである.

$$
S_{d}=K(1+\varepsilon)
$$

すなわち全体の $S(\varepsilon)$ は $S_{b}$ と $S_{d}$ との総合である.

e. 新理論が 0 板厚理淪1)および塑性波構造論1ををと 航身の内に特殊ケースとして含みえるための条件法：

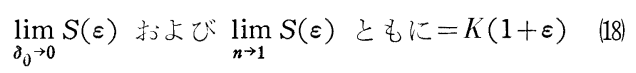

となることである**. この装請から $S_{b}$ と $S_{d}$ とは， $\kappa_{0}$ 位 相点で連絖に接繶しなければならない。

\section{4. 解 法}

\section{1 前 段}

う程式(12) $\theta$ を 0 とおいてみるとつぎのようになる。

$$
\frac{\partial^{2} x}{\partial t^{2}}=\frac{\partial}{\partial \xi} S(\varepsilon), \quad \frac{\partial^{2} z}{\partial t^{2}}=\varphi(t)
$$

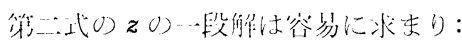

$$
z(\xi, t)=\int_{0}^{t} \mathrm{~d} t \int_{0}^{t} \varphi(t) \mathrm{d} t+A(\xi) t+B(\xi)
$$

となるが，初期膛界条件

$$
z(\xi, 0)=z(0, t)=0
$$

によって $A, B$ はともに消え, $\varphi(t)$ に 0 板厚理䑳同様の 方形波老䢐用寸机ばつぎのようになる.

$$
\left.\begin{array}{ll}
z=\frac{1}{2}(U / T) t^{2} & {[\text { 領域 (a)] }} \\
z=U(t-T / 2) & {[\text { 領域 (b)] }}
\end{array}\right\}
$$

なお領域（a)，(b) 後の表 1 中の烰表に示与。 


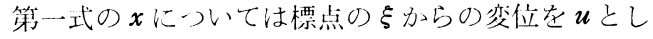
$x=\xi+u$

$\therefore \quad \partial^{2} x / \partial t^{2}=\partial^{2} u / \partial t^{2}$

この24の $u$ に(13)の式を適州し，末た

$$
\frac{\partial}{\partial \xi} S(\varepsilon)=\frac{d S}{d \varepsilon} \cdot \frac{\partial \varepsilon}{\partial \xi}
$$

の $\partial \varepsilon / \partial \xi に(9)$ のを適用して(19)式を変形与ると*,

$$
\mathrm{d} S / \mathrm{d} \varepsilon=K \tau^{-2} \text { ここに } K=m_{0} \gamma^{2}
$$

これから定まる $S$ が方針 bの $S_{b}$ である。こ在実際求 めるには $(9)$ からて逆に解いて，

$$
\tau=(1 / n)\left\{1+(n-1) \sqrt{\varepsilon / \varepsilon_{1}}\right\} \quad\left(0 \leqq \varepsilon \leqq \varepsilon_{1}\right)
$$

これを(26)に代入すると

$$
\frac{\mathrm{d} S}{\mathrm{~d} \varepsilon}=\frac{K n^{2}}{\left\{1+(n-1) \sqrt{\varepsilon / \varepsilon_{1}}\right\}^{2}} \quad\left(0 \leqq \varepsilon \leqq \varepsilon_{1}\right)
$$

こ机を $\kappa_{0}$ 点における関数 $S$ の連続性の要請 (オj針 $\left.\mathrm{e}\right) に$ 従い， $\varepsilon=\varepsilon_{1}$ において $S=K\left(1+\varepsilon_{1}\right)$ の条件で解くと,

$$
\begin{gathered}
S=K\left(1+\varepsilon_{1}\right)+2 \varepsilon_{1} K\left(\frac{n}{n-1}\right)^{2}\left[\ln \left\{1-\frac{n-1}{n}\left(1-\sqrt{\varepsilon / \varepsilon_{1}}\right)\right\}\right. \\
+\frac{n-1}{n} \cdot \begin{array}{c}
1-\sqrt{\varepsilon / \varepsilon_{1}} \\
\left.1+(n-1) \sqrt{\varepsilon / \varepsilon_{1}}\right]\left(0 \leqq \varepsilon \leqq \varepsilon_{1}\right)
\end{array}
\end{gathered}
$$

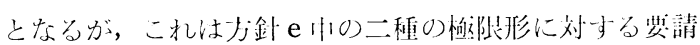

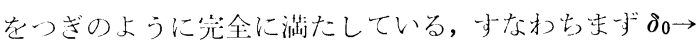
0 に刘しては，2 節の始めに逨べた $\varepsilon_{1} 0$ 走:笺(1)式：

$$
\varepsilon_{1}=\frac{1}{2} \kappa_{0} \delta_{0}
$$

から $\delta_{0} \rightarrow 0$ のとき $\varepsilon_{1 \rightarrow 0}$ となり，(29)式の成立与る倐段 $\left(0 \leqq \varepsilon \leqq \varepsilon_{1}\right)$ そのものが消失するので, 結周(17)式の $S=K$ $(1+\varepsilon)$ だけが基礎的硬化法則として残る.

また $n \rightarrow 1$ の場合 $n-1=\nu 《 1$ としての $S$ の剭開は

$$
S=K(1+\varepsilon)-2 \nu K\left(\sqrt{\varepsilon \varepsilon_{1}-\varepsilon}\right)+\nu \text { の高次式 (30) }
$$

となるので, $\lim _{n \rightarrow 1} S=K(1+\varepsilon)$ となることがわかる.こ れによって前段の問題はうj針通りにかたずいた。なお(29) 式による $S(\varepsilon)$ を一例を用いて示した線図が図 3 である。

\section{2 後 段}

方針 dにはまだあいまいな点があるので，それを明確 にしなけ机ならない。(16)の第一式では質点の水平方向

*11 の第一式に(24) と(25)とを加味すると連動方程式は $\partial^{2} u / \partial t^{2}=$ $(\mathrm{d} S / \mathrm{d} \varepsilon) \partial \varepsilon / \mathrm{d} \xi$ となる. Karman $~^{4)}$ の流派に従う M. P. White $~^{5)}$ は張力として $S(\varepsilon)$ を, Malven ${ }^{6)}$ その他は $\varepsilon の$ 他にひずみ速度字も考慮して $S(\varepsilon, \dot{\varepsilon})$ をまず仮定してこの張 力問題を解いた. 結果の $\varepsilon$ はもとより(9) (11) とは別物であっ て実験とはうまく合わない．また $S$ に真実性を与えるために $\varepsilon$ の他に $\dot{\varepsilon}$ を加味しても, さらに発生熱の効果およびその伝 導輻射の問題は残る.もとよりそれを究めることはレオロジ 的に重要な意味をもつであろうが，いまの場合その追及は避 けたがよい。ここでは既知のひずみ をを用いて逆に $S$ を分 める方法を選んだ。

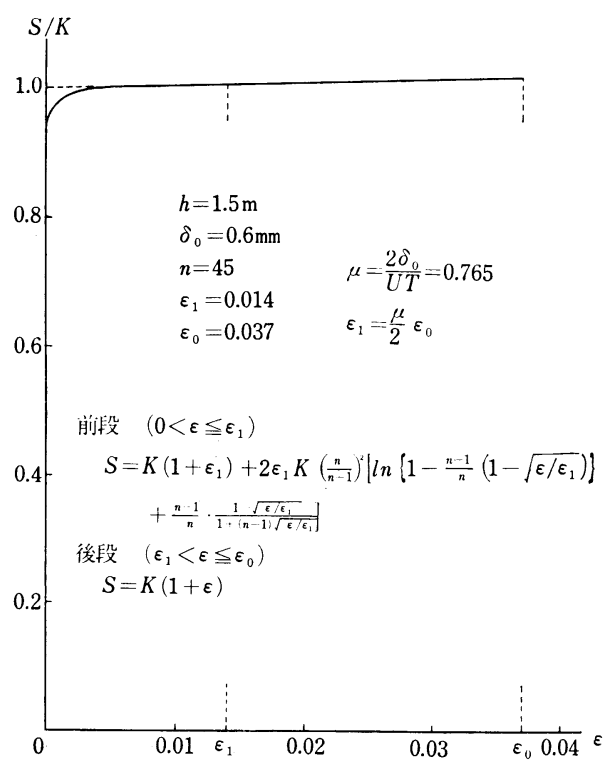

园 3 鉛板の場合の $S(\varepsilon)$ 曲線の例

の空䦌座槽は $\left(1-\lambda_{1}\right)$ の比率で標点座標から絔儿でいる。 そこで素板が運動を起こ少以朔にその收縮を受け，しか る後(17)式の基本法則に彷って(16)の運動を与をと考えても 結果は同じとなるであるう。そ机をつぎのようにして倠

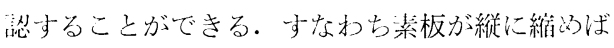

質量は： $\quad \bar{m}_{0}=m_{0} /\left(1-\lambda_{1}\right)$

硬化率は： $\quad \bar{K}=K\left(1-\lambda_{1}\right)$

とすべきであるう。すなわち(25式の規則を聥用して

$$
c^{2}=\bar{K} / \bar{m}_{0}=K\left(/ m_{0}\right)\left(1-\lambda_{1}\right)^{2}
$$

この関係(31)は(26:式を介して(15)と一致する.このようにし て双曲線型方程式(16)の成立には，まったく新しい角度心 らの合理的基醍が与えられた。これを前と同㥞な方形波 衝撃を $\varphi(t)$ に仮定して解いた絬果, 前段のそれとまと めて整理したものを次節に述べる.

\section{3 解の総まとめ}

これは式をただ並べるよりも表にしたほうが見やす い. その表 1 は縦割りにして, 左側に元の標点座標から の質点の $x$ j向変位 $u(x=\xi+u)$ を，また右側には各質 点の時間 $t$ における $z$ 座標の $x$ 座標に対する関係を, そ れぞれ前段，後段を上下に分離して示してある. そして $x$ 方向変位 $u$ のそれぞれの式が成立する $(\xi, t)$ 平面上の 領域はギリシャ交字のアルファベットで下の領域図に記 入し, また $z$ 方向の变位 $(z$ 座標) も同様な方法で表と 英交字のアルファベットを記入した $(x, t)$ 平面の領域図 を用いて整理してある。図4 (a) は両方の領域図を重ね たものであるが，たとえばある時点 $t$ は図中の横軸に平 
表 1 質点の变位およびその変位を示す領域

\begin{tabular}{|c|c|c|c|c|}
\hline & & $x$ 万们変位 $(u)$ & & $z$ 方们変位. $(z)$ \\
\hline & a) & 0 & (a) & $\frac{1}{2}\left(\begin{array}{l}U \\
T\end{array}\right) t^{2}$ \\
\hline 前 & & $\begin{array}{l}-\varepsilon_{1} \frac{n \gamma t}{(n+1)^{2}} \\
\left(\frac{n \gamma t}{\hat{\xi}} \frac{\dot{\varepsilon}}{n \gamma t} 2 \ln \frac{n \gamma t}{\hat{\xi}}\right)\end{array}$ & (b) & $U t-\frac{1}{2} U T$ \\
\hline$x_{0} \cdot(2)$ & & $-\varepsilon_{1} \frac{n \dot{\varepsilon}}{(n-1)^{2}}\left(n-\frac{1}{n}-2 \ln n\right)$ & (c) & $U t-\frac{1}{2} U T$ \\
\hline \multirow{3}{*}{\multicolumn{2}{|c|}{ 後 }} & \multirow{3}{*}{$-\varepsilon_{1} \frac{n \hat{\xi}}{\left(\frac{1}{n-1)^{2}}\right.}\left(n-\frac{1}{n}-2 \ln n\right)$} & (d) & $\frac{1}{2} \frac{v}{T} t^{2}-\frac{1}{2} \frac{U}{T}\left(t-\frac{x}{c}\right)^{2}$ \\
\hline & & & (e) & $U t-\frac{1}{2} U T-\frac{1}{2} \frac{U}{T}\left(t-\frac{x}{c}\right)^{2}$ \\
\hline & & & (f) & $\left(\frac{U}{c}\right) x$ \\
\hline
\end{tabular}
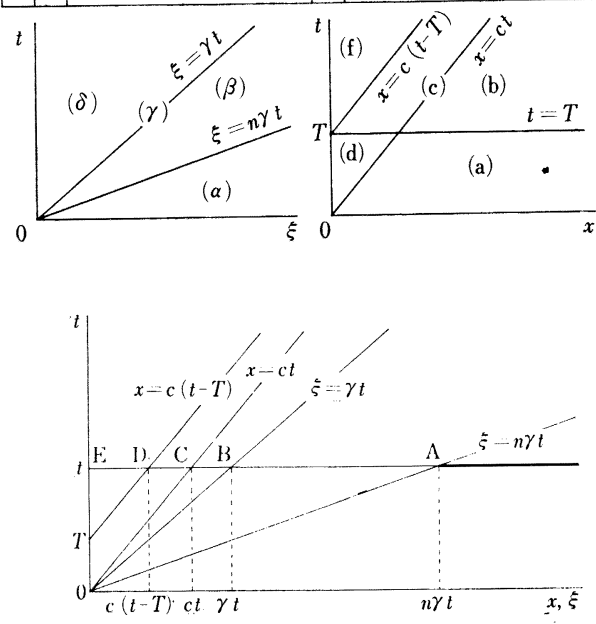

図 4 (a) 表 1 の種の領域を重盢したもの

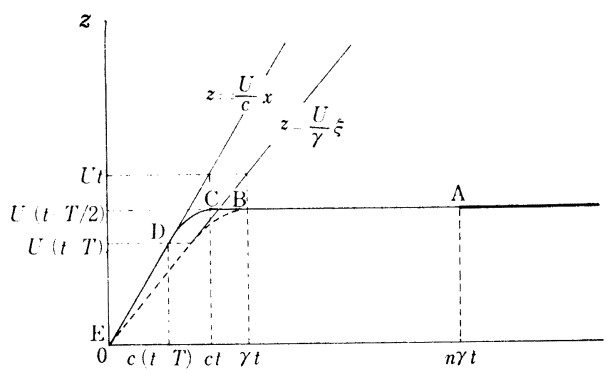

図4(b) 時点 $t$ における板のプロフィル(a), (b) 図 の $\mathrm{A}, \mathrm{B}, \mathrm{C}, \mathrm{D}, \mathrm{E}$ は板の質点を表わす

行線で示されている.この直線上の $\mathrm{A} よ り$ 右の部分の質 点は $x$ 方向は皆不動で $x=\xi$, また線分 $\mathrm{CE}$ はもと $\mathrm{BE}$ 上 にあったものが一様に縮んだ関係でその位置にきて $x$ 方 向に静止（そのうちC D部分は $z$ 方向に運動中で, $\overline{\mathrm{DE}}$ 部分はまったく静止), 残り $\overline{\mathrm{AC}}$ の部分は素板のとき $\overline{\mathrm{AB}}$ の長さであったものが, 表中の $(r)$ 欄に示された式の值 だけ伸長してできたものである.

図 4 (b) 注上と同じ時点 $t$ における板のプロフィル線 図を示す．Aより右方の太線部分はまだ素板状態にあり 左端の傾斜部分 $\overline{\mathrm{ED}}$ 清静止, 放物線弧 $\mathrm{D} \mathrm{C}$ は C 端が上昇
して $\overline{\mathrm{ED}} \overline{\mathrm{D}}$ の延长上に達寺る時帒に静止（獚方向の運動を 含まず)、つぎに $\mathrm{C} \bar{A}$ 部分は素板長 $\mathrm{B} \overline{\mathrm{A}}$ に相当する長さ のものが伸びてできたもので $\mathrm{C} \mathrm{A}$ ： B A の伸長比法時間 と滩係なく一走である。その比の值は脳 4 (b) と式(15) により

$$
\frac{n \gamma-c}{n \gamma-\gamma}=\frac{n-1+\lambda_{1}}{n-1}=1+\frac{\lambda_{1}}{n-1}
$$

これは $\lambda_{1} /(n-1)$ が非常に小さいので，現実的にはほと えど 1 とみてよ.

\section{5. 結言}

これまでの一連の理論は実験との密接な連係を保ちな がら進められてきたが，その意味では理論というより実 験式の構成といったほうが適当かも知れない，今回は前 回までの理論相互の間および実験結果との間のちぐはぐ に対して理論的調整を試みて結局つぎの結果を得た。

1. 板厚 $\delta_{0}$ が十分薄い $\left(<\frac{1}{2} U T\right)$ ときの横衝撃によ る二次元変形は，プロフィルの形だけを問題にするとし たら，0板厚の理淪で十分よく説明できる.

2. ひずみを問題とする壦合は，最大曲率 $\kappa_{0}$ の起き る位相点において(1)式により $\frac{1}{2} \kappa_{0} \delta_{0}$ の伸びが生じ，そ れは秦板上を $\kappa_{0}$ とともに，速度 $\gamma$ (刘標点座標)で伝ぱ することになる。亦なおちその前少には, 先端が弾性縦 波の速度（百速）をもった伸びをの波が進んでいく、い ま板を伀わる穴速を $\gamma_{c}$ とすると， $\kappa_{0}$ より前方の $\varepsilon$ の波 形は

$$
\varepsilon=\frac{1}{2} \kappa_{0} \delta_{0} \cdot\left(\begin{array}{c}
\gamma_{c} \\
\gamma_{c}-\gamma
\end{array}\right)^{2}\left(\frac{\gamma t}{\xi}-\frac{\gamma}{\gamma_{c}}\right)^{2}
$$

となる。これは時間 $t$ の二次式であって, 標点 $\xi$ におい てシンクロスコープにとった波形の立ち上りは $t=\xi / \gamma_{c}$ に始まる放物線になることを主張する。

3. $\kappa_{0}$ より背後の部分では, 伸び $\varepsilon$ は $\frac{1}{2} \kappa_{0} \delta_{0}$ から最 大值 $\varepsilon_{0}$ まで, ほとえどまったく 0 板厚理論の示す法則 に従いながら，曲率 $\kappa$ の減少に応じて増加する.

4. 以上のような現像が起こるためには, 板の㖘力に よる硬化法則 $S(\varepsilon)$ は， $\kappa_{0}$ 以前で(29式， $\kappa_{0}$ 以後で(17)式と なることが必要十分である。

5. 板厚 $\delta_{0} \rightarrow 0$ および $\gamma_{c} \rightarrow \gamma$ の極限においてともに $\lim S(\varepsilon)=K(1+\varepsilon)$ となる.この事実から 0 板厚理論も， 塑性波構造論もともに新理論の特殊ケースとなることが 明らかにされる。

6. 新理論に関する実験その他の報告は次回以後に譲 る.

なお本研究に対しては特に東京大学の前田禎三教授よ り蕙切なるご指導を賜わりました。 またこれに関する実 
験関係では熊本大学の清田堅吉教授より多大の便宜とア ドバイスを賜わりました。ここにあわせて深い感謝の気 持を述べさせていただきます.

\section{文献}

1）泉 四郎, 坂田正登: 精密機械, 35, 6 (1969).

2) 泉 四郎, 坂田正登, 满田博宣: 精密機械, 36, 12 (1970).

3）泉四郎, 坂田正登, 満田博宣: 昭和 44 年度九州地方学術
講演会前刷 (1969).

4) T. von Karman, P.E. Duwez: On the Propagation of Plastic Deformation in Solids, J. Appl. Phys., 21, (1950).

5) M.P. White, L. Griffis: The Parmanent Strain in a Uniform Bar Due to Longitudinal Impact, Trans. Amer. Soc. Mech. Engrs., 69 (1947).

6) L.E. Malvern: Plastic Wave Propagation in a Bar of Material exhibiting a Strain-Rate Effect, Quart. Appl. Math., 8 (1951).

\begin{tabular}{cc}
\hline 情 \\
\hline
\end{tabular}

\section{科学枝術情報センタークリアリングサービスを開設}

日本科学技術情報センター（東京都千代田区永业町 2 -5-2，理事長児玉宽一氏）は NIST（科学技術情報の全 国的流通システム）の一檌として，47 年度からクリアリ ング・サービスを閒設玄る方針である。このため近いう らにプロジェクト・チーム花練成，クリアリング・サー ビス業枒尖施の準借にはいる。タリアリング・サービス

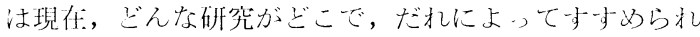
ているぬといった研究活動に久な女ない科器技術情献を 的確に提供しようという業務で，これが軌道に乘机ば， わが国研究機関の科学技術情㪲收集に人いに役立つこと が期待されている.

現在，わが国には理工学，農兴，医学など日然科学:系 だけでも研究者がざっと17 万人おり, 国立破究機瀜,

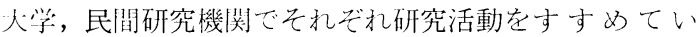
る。しかし，これらの研究者がよ゙んなテーマでどんな研 究を行なっているか的確な情報はつかめない。とくに科 学技術の進歩にともない各研究部归も尃桦し, 細分化 の方向にあることから，その情報収集はますま少劣ずか しくなってきた。

こういった傾向はわが国だけに限ったことでなく，す でにアメリカではこれらに刘処して米国議会脳書馆の 「ナショナル・リファランス・センター」スミスソニア ン協会の「サイエンス・インフォメーション・エクスチ
ェンジ」などでクリアリング・サービスを実施，成果を あげている。しかし，わが国では科学技術打の NIST 計 画に盛られているものの，実現していない。

日本科学技術情報センターが実施するクリアリング・ サービスは科学技術庁の NIST 計画の一䍗として行なう もので，わが国の研究者がどんな研究をすすめているか といった情報を提供サービスしていくのが权らい。行研 究機関の研究者が取組んでいる研究テーマやや内谷，進行 状海など情報をキャッチ，ユーザーに的確な情報が提供 でき机ば，互いに研究の重複によるムダがさりられる半

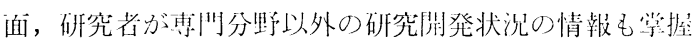
尗ることがだき，研究活動に役立つということになる。

このため科学技術庁の付属機闺である日本科学技術情 報センターは，プロジェクトチームをつくり，クリアリ ング・サービス実施の準備工作を行なっていくことにな ったわけで，科学技術庁に対し，46 年度の啭算要求額 1300 万円を計上した同七ンターではこれによって情報 収集活動を実施し，さしあたり来年 4 月にはクリアリン グ課を開設，サービス業務を行なっていく方針である.

また同サービス業務の充実を注かるため，さらに2 年 計画でクリアリング・センタ一設立も計画されている. クリアリング・サービスが軌道に乘机ば科学: 技術庁の NIST 計画は一歩前進する.

(59 頁へつヴく) 